\title{
Efficacy and Predictive Factors of the Outcome of Extracorporeal Shock Wave Lithotripsy: A Review of One-thousand-nine-hundred- ninety-seven Patients
}

\section{Ekstrakorporeal Şok Dalga Litotripsisinin Etkinliği ve Başarısındaki Belirleyici Faktörler: Bin Dokuz Yüz Doksan Yedi Hastanın Derlemesi} \author{
(D) Hüseyin Kocatürk5, (D) Yılören Tanıdır6 \\ ${ }^{1}$ Trabzon Kanuni Training and Research Hospital, Clinic of Urology, Trabzon, Turkiye \\ 2Bilecik State Hospital, Clinic of Urology, Bilecik, Turkiye \\ ${ }^{3}$ Atatürk University Faculty of Medicine, Department of Urology, Erzurum, Turkiye \\ ${ }^{4}$ Kanuni Training and Research Hospital, Clinic of Pediatric Urology, Trabzon, Turkiye \\ 5Erzurum Training and Research Hospital, Clinic of Urology, Erzurum, Turkiye \\ ${ }_{6}^{6}$ Marmara University Faculty of Medicine, Department of Urology, Istanbul, Turkiye
}

(D) Hüseyin Koçakgöl1, (D) Ali Haydar Yılmaz², (D) Turgut Yapanoğlu33, (D) Fatih Özkaya3, (D) Çağrı Akın Şekerci4, (D) Fevzi Bedir5,

\section{What's known on the subject? and What does the study add?}

Extracorporeal shock wave lithotripsy (ESWL) is an easy, effective, reliable and non-invasive method and therefore is an alternative modality to surgery in patients with urinary stone disease. However, with the development of endoscopic treatment methods, it has become less preferred by urologists. ESWL can be used effectively and safely in appropriate patients.

\section{Abstract}

Objective: The aim of this study was to evaluate the efficacy and safety of extracorporeal shock wave lithotripsy (SWL) in a large patient group treated with SWL due to kidney stone.

Materials and Methods: Data of 1997 patients, who underwent SWL due to renal stone in the at Atatürk University Medical Faculty Clinic of Urology between 2008 and 2013, were evaluated retrospectively. The effect of age, gender, stone location, size and opacity on SWL success, additional procedure requirement and complication rates were evaluated.

Results: Six hundred eighty-six patients were female and 1311 were male. The overall rate of success of SWL was found to be $82.6 \%$. The rate of success of SWL was $82.1 \%$ in female patients and $82.9 \%$ in male patients ( $p>0.05$ ). Gender, stone location, stone size and opacity were significant predictive factors for the success of SWL $(p<0.05)$. The complication rate in stones $>15 \mathrm{~mm}$ was $5.8 \%(p<0.05)$. Age, gender, stone size, stone location and stone opacity were not predictive factors for additional treatment after SWL $(p>0.05)$.

Conclusion: Although SWL is less preferred today with the increase of endourological interventions, it remains an effective treatment method in appropriate patients.

Keywords: Extracorporeal shock wave lithotripsy, Urinary stone, Complication

$\ddot{0} z$

Amaç: Bu çalışmamızdaki amacımız böbrek taşı nedeniyle ekstrakorporeal şok dalga litotripsinin (ESWL) ile tedavi edilen geniş hasta grubunda etkinliğinin ve güvenirliğinin değerlendirilmesidir.

Correspondence: Çağrı Akın Şekerci MD, Kanuni Training and Research Hospital, Clinic of Pediatric Urology, Trabzon, Turkiye E-mail: cagri_sekerci@hotmail.com ORCID-ID: orcid.org/0000-0002-0334-2466

Received: 23.01.2019 Accepted: 13.03.2019

Cite this article as: Koçakgöl H, Yılmaz A.H, Yapanoğlu T, Özkaya F, Sekerci C.A, Bedir F, Kocatürk H, Tanıdır Y. Efficacy and Predictive Factors of the Outcome of Extracorporeal Shock Wave Lithotripsy: A Review of One-thousand-nine-hunderd-ninety-seven Patients. J Urol Surg 2019;6(3):207-212.

๑Copyright 2019 by the Association of Urological Surgery / Journal of Urological Surgery published by Galenos Publishing House. 
Gereç ve Yöntem: 2008-2013 yılları arasında Atatürk Üniversitesi Tıp Fakültesi Üroloji Kliniğinde böbrek taşı nedeniyle ESWL yapılan 1997 hastaya ait veriler retrospektif olarak değerlendirildi. Yaş, cinsiyet, taş lokalizasyonu, taş boyutu ve taş opasitesinin ESWL başarısına etkisi, ek prosedür gereksinimi ve komplikasyon oranları değerlendirildi.

Bulgular: Hastaların 686'sı kadın ve 1311'i erkekti. ESWL'nin tüm hastalardaki başarısı \%82,6 olarak bulundu. Kadın hastalarda ESWL başarısı \%82,1, erkek hastalarda \%82,9 idi ( $>>0,05)$. ESWL başarısında cinsiyet, taş lokalizasyonu, taş boyutu ve opasite önemli belirleyici faktörler olarak öne çıktı $(p<0,05)$. Komplikasyon oranı $>15 \mathrm{~mm}$ ebatlı taşlarda \%5,8 ile yüksek bulundu $(p<0,05)$. Ek prosedür gereksiniminde değerlendirilen faktörler arasında anlamlı fark bulunmadı $(p>0,05)$.

Sonuç: ESWL günümüzde endoürolojik girişimlerin artması ile ikinci plana düşse de uygun hastalarda etkili bir tedavi yöntemi olarak değerini korumaktadır.

Anahtar Kelimeler: Ekstrakorporeal şok dalga litotripsi, Taş, Komplikasyon

\section{Introduction}

Urinary stone disease is an important public health problem with a prevalence of about $8.8 \%$ worldwide. It has been reported that urinary stone disease has an annual health care cost of $\$ 3.8$ billion in the United States (1). Extracorporeal shock wave lithotripsy (SWL) has been widely accepted as a non-invasive treatment method after it was first described by Chaussy et al. (2) in 1980. With the developments in endoscopic treatment techniques, ureteroscopy has replaced SWL as the most commonly performed treatment for renal stones in recent years. However, SWL is still an important treatment option in patients with stone disease because it is an easy, practical, effective, non-invasive and mostly non-anesthetic treatment method. However, SWL can cause complications such as hemorrhage, infection, hematoma and renal colic. The widespread availability of alternative treatment methods, such as percutaneous nephrolithotomy (PCNL) and retrograde intrarenal surgery (RIRS), in urology practice forced urologists to be more careful in SWL indications. In this study, we aimed to investigate the success and side effects of SWL in a large group of patients retrospectively. To our knowledge, this study that investigated the effectiveness of SWL in the highest group of patients in Turkiye and it is among the top ten studies according to the number of patients in the English literature.

\section{Materials and Methods}

A total of 1997 patients treated with SWL at Atatürk University Medical Faculty Research Hospital between 2008 and 2013 were evaluated retrospectively. The demographic data of the patients, including age, gender, stone size, stone opacity and stone location, were recorded. Stone size was obtained by measuring the largest diameter in millimeters using ultrasonography (US), X-ray or computed tomography (CT).

All patients were treated using a Siemens Lithostar Modularis device. In our clinic, SWL is not performed in patients with urinary tract infection, stenosis distal to stone, morbid obesity, staghorn stone, aortic aneurysm, cardiac pacemaker and bleeding diathesis and those using antiplatelet agents. All patients were evaluated by X-ray, urinary US and, if necessary, intravenous urography and/or non-contrast CT. Each patient was treated with a minimum of 8 hours of fasting, and a maximum of 3 sessions of SWL. No routine general anesthesia was performed before SWL. However, children and patients, who could not tolerate SWL, were treated with sedation by the anesthesia team before the procedure. The SWL was performed with a dose of 2000-3000 shocks. For each patient, low-energy operation was initiated, and the energy increased by assessing the patient tolerance and whether or not the stone was fragmented. Radiopaque stones were visualized with fluoroscopy, radiolucent stones with special probe integrated into the US device. In patients with radiopaque stones, the stone was checked with fluoroscopy in every 500 shock. In patients with radiolucent stones, the procedure was continuously monitored with US. No routine antibiotic or medical expulsive treatment was performed before or after the treatment. The patients were advised to consume plenty of fluid after the procedure. After the treatment, all patients were given an appointment for SWL. All patients were re-evaluated by kidney, ureter, and bladder (KUB) X-ray or US before the second and third session. The procedure was considered to be successful in patients with no stone fragments or with any stone fragments smaller than $4 \mathrm{~mm}$ in size. Stones smaller than $4 \mathrm{~mm}$ were considered clinically insignificant stone fragments (3). Patients, who had fragmented stones but were not stone-free, were followed. Patients who had a significant residual stone $(>4 \mathrm{~mm})$ or stones not fragmented after SWL were treated with alternative treatment methods. The success of SWL was evaluated according to age, sex, stone location, stone opacity, stone size, complication rate and additional procedure in all patients. The patients were divided into two groups based on age greater or less than 40 years old (3). We also evaluated patients under the age of 18 as a separate group. We defined the stone size range values $(<10 \mathrm{~mm}, 10$ $15 \mathrm{~mm},>15 \mathrm{~mm}$ ) according to the European Association of Urology (EAU) Guidelines On Urolithiasis and the Study by Politis and Griffith (4). We calculated efficiency quotient (EO) of SWL in respect to stone location. EO was assessed using 
the following formula EQ = percentage stone free $/[100 \%$ (1 treatment) + percentage requiring retreatment + percentage requiring auxiliary procedure] $\times 100 \%(5,6)$. The problems that required hospitalization after a SWL session were stone-street, severe renal colic or retroperitoneal hematoma. Alternative treatment techniques were recommended in patients without SWL response. Patients who did not accept additional treatment and/or patients with non-obstructive stone were followed up.

\section{Statistical Analysis}

The data were analyzed with SPSS version 25.0. The stone-free status was correlated with patient characteristics and various stone features with the aid of t-test and Pearson's chi-squared test. Factors with a significant impact on success rate were further analyzed using multivariate analysis (stepwise logistic regression model with backward elimination using the likelihood ratio) to identify independent predictors of the success of SWL treatment. A p value of less than 0.05 was considered statistically significant.

\section{Results}

Of the 1997 patients, $686(34.3 \%)$ were female and 1311 $(65.6 \%)$ were male. The patients were evaluated in three different age groups: $0-18,18-40$ and $>40$ years. SWL success rates were $90.2 \%, 84.5 \%$ and $79.2 \%$, respectively (Table 1 ). Age was a statistically significant predicting factor for SWL success. SWL success rate decreased as the age of the patients increased $(p<0.001)$. The success rate of SWL was $82.1 \%$ in male patients and $82.9 \%$ in female patients ( $p>0.05$ ). The rate of success of SWL in the lower pole, middle pole-pelvis and upper pole stones was $73.7 \%, 83.4 \%$, and $88.5 \%$, respectively. The success rate of SWL was lower in the lower pole than in the middle pole and pelvic stones $(p<0.001)$. SWL success rates for stone groups $<10 \mathrm{~mm}, 10-15 \mathrm{~mm}$ and $>15 \mathrm{~mm}$ were found to be $89.9 \%$, $81.7 \%$ and $60.8 \%$, respectively. The rate of success of SWL in radiopaque stones was $80.6 \%$, and in non-radiopaque stones was $88.6 \%(p<0.001)$ (Table 1).

Four factors (age, stone location, stone opacity and stone size) were further analyzed using a logistic regression model, which resulted in the exclusion of the nature of the stones from the model, while the other prognostic factors maintained their statistically significant effect on ESWL outcome, indicating that they acted independently (Table 1). The sensitivity of the model was $60.7 \%$, the specificity $83.2 \%$ and the overall accuracy was $82.9 \%$. Using the regression model, we can define the stonefree ratio of a certain category in comparison to the reference category (Table 1), as Exp (B) sets for the odds ratio. For example,

Table 1. Demographic data and stone parameters were provided with stepwise logistic regression model

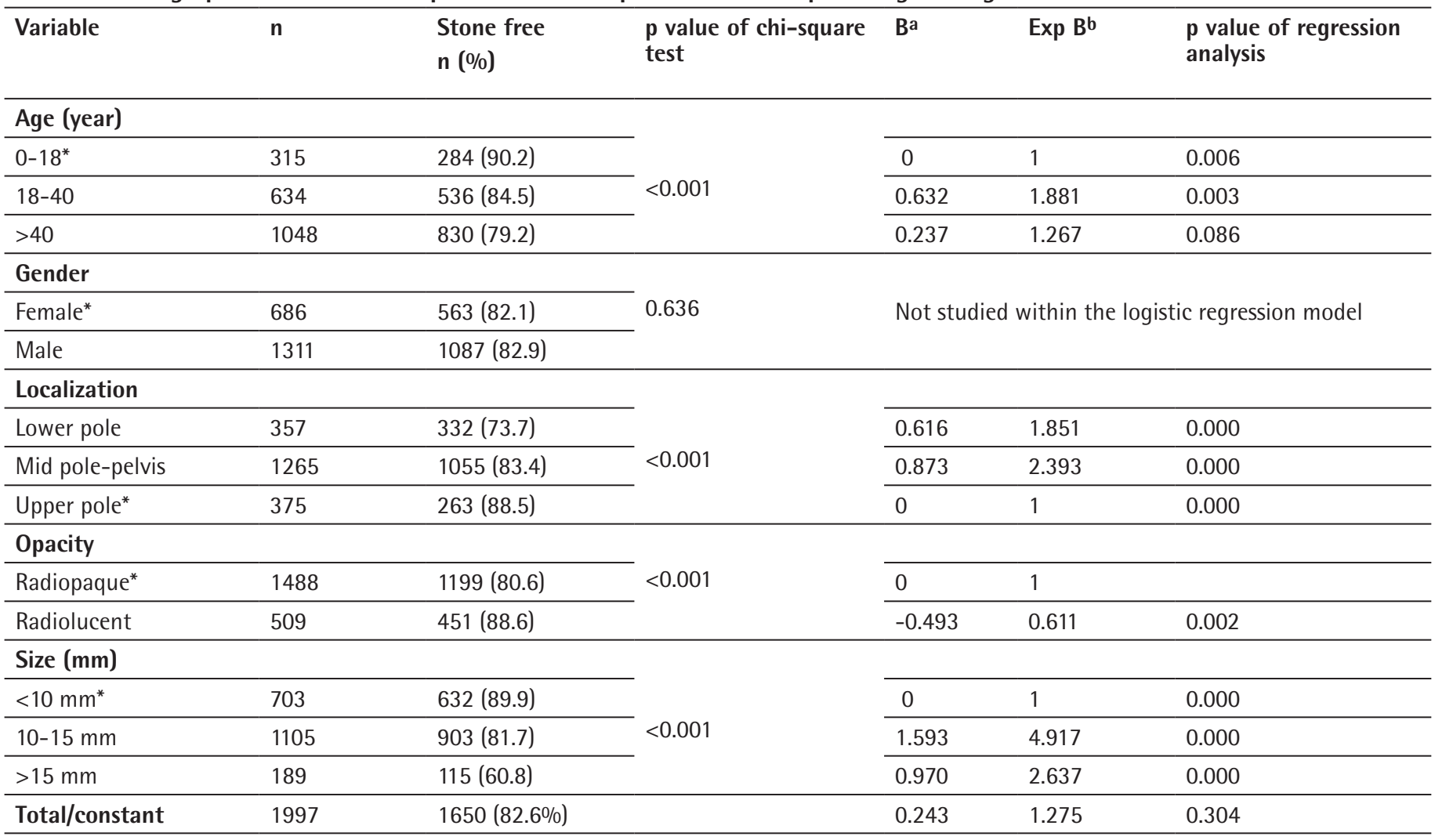

NS: Not significant

aRegression coefficient, bStone-free rate when the category of a certain variable is compared to the reference category which is indicated with* 
the probability of stone-free status is 4.917 times greater for patients with stones $10-15 \mathrm{~mm}$ in size in comparison to patients with stones $<10 \mathrm{~mm}$ in size.

68 patients had stone-street, 4 patients had renal hematoma and 2 patients had urinoma after procedure. The complication rate was found to be $5.8 \%$ in stones $>15 \mathrm{~mm}(p<0.001)$ (Table 2). A total of 141 patients underwent additional procedures as complementary or secondary to complications. 49 patients were treated with ureterorenoscopy, 49 patients with PCNL, 42 patients with double J stent placement and 1 patient with ureterolithotomy (Table 3). In our study, it was observed that age, gender, stone location, stone size and opacity parameters did not create any statistically significant difference in the need for additional procedure $(p>0.05)$.

EQ values were calculated based on stone locations. EQ rates were $45.7 \%$ for lower pole, $55.9 \%$ for middle pol-pelvis, $65 \%$ for upper pole and total EQ was found to be 55.5\% (Table 4).

Table 2. Complication rates with demographic data and stone parameters

\section{Number (n) Complication $\quad p$}

(\%) (n)

\begin{tabular}{|c|c|c|c|}
\hline Age (year) & & & \\
\hline $0-18$ & 315 & $0.6 \%(2)$ & \multirow{3}{*}{0.063} \\
\hline $18-40$ & 634 & $1.9 \%(12)$ & \\
\hline$>40$ & 1048 & $2.8 \%(29)$ & \\
\hline \multicolumn{4}{|l|}{ Gender } \\
\hline Female & 686 & $2.9 \%(20)$ & \multirow{2}{*}{0.090} \\
\hline Male & 1311 & $1.8 \%(23)$ & \\
\hline \multicolumn{4}{|l|}{ Localization } \\
\hline Lowerpole & 357 & $3.4 \%(12)$ & \multirow{3}{*}{0.155} \\
\hline Midpole-pelvis & 1265 & $2.1 \%(26)$ & \\
\hline Upperpole & 375 & $1.3 \%(5)$ & \\
\hline \multicolumn{4}{|l|}{ Opacity } \\
\hline Radiopaque & 1488 & $2.3 \%(34)$ & \multirow{2}{*}{0.488} \\
\hline Radiolucent & 509 & $1.8 \%(9)$ & \\
\hline \multicolumn{4}{|l|}{ Size $(\mathrm{mm})$} \\
\hline$<10 \mathrm{~mm}$ & 703 & $1.0 \%(7)$ & \multirow{3}{*}{0.001} \\
\hline $10-15 \mathrm{~mm}$ & 1105 & $2.3 \%(25)$ & \\
\hline$>15 \mathrm{~mm}$ & 189 & $5.8 \%(11)$ & \\
\hline Total & 1997 & $2.1 \%(43)$ & \\
\hline
\end{tabular}

\section{Discussion}

SWL has been recognized as a safe and non-invasive treatment method for ureteral stones smaller than $20 \mathrm{~mm}$ and uncomplicated kidney stones since its introduction in the 1980s. In most cases, SWL can be performed without anesthesia or with minimal anesthesia (7). Many studies have shown that factors such as stone size, skin-to-stone distance, severity of obstruction, obesity, urinary tract anatomy and the type of device used are effective in predicting SWL success. As we retrospectively evaluated the data, we could not provide data for stone density, distance, energy applied per session and obesity. In our study, the effect of age, gender, stone size, location and opacity on SWL results was evaluated. The effect of the age factor on SWL success is controversial. In a few studies, the age factor was found to be important in predicting SWL

Table 3. Additional procedure with demographic data and stone parametres

$\begin{array}{ll}\text { Number } & \begin{array}{l}\text { Additional } \\ \text { procedure }\end{array}\end{array}$

(\%) (n)

\begin{tabular}{|c|c|c|c|}
\hline Age(year) & & & \\
\hline $0-18$ & 315 & $7.6 \%(24)$ & \multirow{3}{*}{0.516} \\
\hline $18-40$ & 634 & $7.0 \%(45)$ & \\
\hline$>40$ & 1048 & $6.8 \%(72)$ & \\
\hline \multicolumn{4}{|l|}{ Gender } \\
\hline Female & 686 & $7.4 \%(51)$ & \multirow{2}{*}{0.692} \\
\hline Male & 1311 & $6.8 \%(90)$ & \\
\hline \multicolumn{4}{|l|}{ Localization } \\
\hline Lowerpole & 357 & 7.8\% (28) & \multirow{3}{*}{0.584} \\
\hline Midpole-pelvis & 1265 & 7.0\% (89) & \\
\hline Upperpole & 375 & $6.4 \%(24)$ & \\
\hline \multicolumn{4}{|l|}{ Opacity } \\
\hline Radiopaque & 1488 & $7.3 \%$ (108) & \multirow{2}{*}{0.556} \\
\hline Radiolucent & 509 & $6.5 \%(33)$ & \\
\hline \multicolumn{4}{|l|}{ Size $(\mathrm{mm})$} \\
\hline$<10 \mathrm{~mm}$ & 703 & $6.0 \%(42)$ & \multirow{3}{*}{0.372} \\
\hline $10-15 \mathrm{~mm}$ & 1105 & $7.6 \%(84)$ & \\
\hline$>15 \mathrm{~mm}$ & 189 & $7.9 \%$ (15) & \\
\hline Total & 1997 & $7.1 \%(141)$ & \\
\hline
\end{tabular}

Table 4. Efficiency quotient of shock wave lithotripsy in respect to stone location

\begin{tabular}{llllll}
\hline Stone location & $\begin{array}{l}\text { Patients } \\
(\mathbf{n})\end{array}$ & $\begin{array}{l}\text { No. of stones } \\
\text { retreated (\%) }\end{array}$ & $\begin{array}{l}\text { No. of additional } \\
\text { procedures (\%) }\end{array}$ & $\begin{array}{l}\text { No. of stone free } \\
(\%)\end{array}$ & $\begin{array}{l}\text { Effectiveness } \\
\text { quotient (\%) }\end{array}$ \\
\hline Lower & 357 & $190(53.2)$ & $28(7.8)$ & $332(73.7)$ & 45.7 \\
\hline Mid-pelvis & 1265 & $533(42.1)$ & $89(7.0)$ & $1055(83.4)$ & 55.9 \\
\hline Upper & 375 & $111(29.6)$ & $24(6.4)$ & $263(88.5)$ & 65 \\
\hline Total & 1997 & $834(41.7)$ & $141(7.1)$ & $1650(82.6 \%)$ & 55.5
\end{tabular}


success (8). In a study evaluating 3023 patients treated with SWL, stone free rates were reported to be significantly lower in the elderly patient group (9). In another similar study evaluating 2954 patients who underwent SWL for kidney stones, stonefree rates were reported to be significantly low in patients over the age of 40 years (3). In our study, it was observed that SWL success decreased with age $(p<0.001)$.

In a study evaluating 235 adult patients treated with SWL, gender was reported as a predicting factor for SWL success. In this study, the rate of success of SWL in men was $82.4 \%$ and $66 \%$ in women (8). In a retrospective study of 145 patients, age, gender and stone location were not statistically significant in predicting SWL success (10). In our study, there was no significant difference in SWL success between female and male patient groups ( $p>0.05)$.

Stone location is another important predicting factor for SWL success. In the EAU Guidelines, SWL is recommended as a firstline treatment with RIRS for renal pelvis, middle and upper pole stones smaller than $2 \mathrm{~cm}$. In a meta-analysis evaluating $S W L$, PCNL and RIRS results, PCNL was found to be more effective at the end of three months, but the duration of treatment, the need for additional treatment and the duration of hospital stay were lower in the SWL group. There was no significant difference between SWL and RIRS results in the same metaanalysis (11). In many studies, high success rates for treatment with SWL have been reported in upper, middle and pelvic stones. However, the best treatment for lower pole stones is still controversial (7). In the literature, the results of SWL for lower pole stones are variable. Stone-free rates for SWL-treated lower pole stones have been reported to be between $47 \%$ and $84 \%$ (8). There are also studies that have different interpretations of the low success rate in SWL for lower pole stones. Nafie et al. (12) reported a stone-free rate of $49 \%$ in lower pole stones; but in this study, the low stone-free rate was attributed to a large number of patients with lower pole stones (43.3\%). In a study of 246 patients with lower pole stones, stone size was reported to be an important predictive factor for SWL success rather than lower pole caliceal anatomy (13). In another study conducted on 714 renal units of 687 patients investigated for isolated calyceal stones, no significant difference was found between treatment of lower, middle or upper pole stones (14). In our study, stone location was prominent as a predictive factor. We found SWL to be more successful in upper pole and middle pole-pelvis stones than those in the lower pole $(p<0.05)$.

In their meta-analysis, Torricelli et al. (15) emphasized that stone size was an important predictive factor for SWL success. In a study of Al-Ansari et al. (16), the success rate in SWL in stones of less than and above $10 \mathrm{~mm}$ was reported to be $90 \%$ and $70 \%$, respectively. Furthermore, in the same study, the authors reported that SWL treatment was more successful in patients with single stone than in those with multiple stones $(p<0.01)$. SWL success was found to be significantly higher in single and middle pole stones (16). In the present study, SWL success in patients with stones $<10 \mathrm{~mm}, 10-15 \mathrm{~mm}$ and $15 \mathrm{~mm}$ was $89.9 \%, 81.7 \%$ and $60.8 \%$, respectively $(p<0.001)$. We concluded that SWL success rate decreased significantly as the stone size increased. According to our study, other minimally-invasive treatments, such as PCNL and RIRS, may be recommended as first-line treatment in patients with stones greater than $15 \mathrm{~mm}$ located in the lower pole.

Elbahnasy et al. (17) reported inferior pole infindubulopelvic (LIP) angle, infundibular length (IL) and infundibular width to be more important in predicting SWL success. In their study, the patients with LIP angle $>70^{\circ}, \mathrm{IL}<3 \mathrm{~cm}$ and IW $>5 \mathrm{~mm}$ were found to be excellent candidates for SWL. Same study suggested to offer PCNL or URS to patients with lower pole stones less than $17 \mathrm{~mm}$ and unfavorable anatomies (LIP angle $<70^{\circ}$ and IW $<5 \mathrm{~mm}$ or IL $>3 \mathrm{~cm}$ ) as SWL success is low in such patients. SWL success rates are adversely affected in patients with congenital renal abnormalities, stone density greater than 1000 Hounsfield Units and a skin-to-stone distance greater than $9 \mathrm{~cm}(16,18)$. Compared to SWL, RIRS and PCNL are more invasive treatment options in pediatric patients. Thus, for any pediatric patient, SWL should be preferred if they are eligible for the treatment. Considering the smaller body size of pediatric patients, higher SWL success rates could be due to shorter skinto-stone distance. Therefore, SWL must be chosen as the firstline treatment in pediatric patients whenever possible.

Some radiological parameters have been evaluated for their ability to predict stone fragility. Bon et al. (19) reported that smooth, uniform calculi that seems denser than bone on KUB responded poorly to SWL. Mandhani et al. (20) concluded in their study that the patients with high stone mineral content should be offered other treatment methods rather than SWL. In our study, the rate of success of SWL in 509 patients with radiolucent stone and 1488 patients with radiopaque stone was $88.6 \%$, and $80.6 \%$, respectively. The success of SWL was statistically significant in patients with radiolucent stone $(p<0.05)$. We assume that the lower mineral content of radiolucent stones and US monitoring during the procedure played a role in the success of SWL.

SWL has several advantages over other minimally-invasive surgical techniques. In a meta-analysis by Junbo et al. (21), it has been reported that SWL offered shortest length of hospital stay and shorter operative time compared to PCNL and RIRS. SWL usually can be applied without anesthesia especially in adult patients. Also cost of operation is another important superiority of SWL. We calculated costs of SWL, RIRS and PNL separately by the fees of Turkish Social Security Institution. 3 sessions of SWL 
cost about \$85, 1 session of RIRS about \$160 and 1 session of PNL costs about $\$ 510$.

\section{Study Limitation}

The study has some limitations. We could not provide data for stone density, skin-to-stone distance, energy applied per session and obesity due to the retrospective design of the study. A follow-up was not done following the last treatment session. Previous treatments were not recorded in the data collection phase.

\section{Conclusions}

The widespread availability and effectiveness of alternative minimally-invasive treatment modalities in urinary stone disease makes us prefer SWL less. However, SWL is a noninvasive treatment that should always be kept in mind because of its high success in suitable stones. In our study, age, stone location, size and opacity were prominent predictive factors for SWL success.

Ethics Committee Approval: Retrospective study.

Informed Consent: Retrospective study.

Peer-review: Externally peer-reviewed.

\section{Authorship Contributions}

Concept: H.K., Design: H.K., Data Collection and/or Processing: H.K., A.H.Y., Analysis and/or Interpretation: H.K., F.Ö., Literature Research: H.K., Writing: H.K., Ç.A.Ş., Y.T.

Conflict of Interest: No conflict of interest was declared by the authors.

Financial Disclosure: The authors declared that this study received no financial support.

\section{References}

1. Fankhauser $C D$, Hermanns $T$, Lieger $L$, Diethelm 0 , Umbehr $M$, Luginbühl T, Sulser T, Müntener M, Poyet C. Extracorporeal shock wave lithotripsy versus flexible ureterorenoscopy in the treatment of untreated renal calculi. Clin Kidney J 2018;11:364-369.

2. Chaussy C, Brendel W, Schmiedt E. Extracorporeally induced destruction of kidney stones by shock waves. Lancet 1980;2:1265-1268.

3. Abdel-Khalek M, Sheir KZ, Mokhtar AA, Eraky I, Kenawy M, Bazeed M. Prediction of success rate after extracorporeal shock-wave lithotripsy of renal stones--a multivariate analysis model. Scand J Urol Nephrol 2004;38:161-167.

4. Politis G, Griffith D. ESWL: stone-free efficacy based upon stone size and location. J World Journal of Urology 1987;5:255-258.

5. Denstedt J, Clayman RV, Preminger G. Efficiency quotient as a means of comparing lithotripters. J Endourol 1990;4:100.
6. Rajaian S, Kumar S, Gopalakrishnan G, Chacko NK, Devasia A, Kekre NS. Outcome of shock wave lithotripsy as monotherapy for large solitary renal stones (>2 cm in size) without stenting. Indian J Urol 2010;26:359-363.

7. Nielsen TK, Jensen JB. Efficacy of commercialised extracorporeal shock wave lithotripsy service: a review of 589 renal stones. BMC Urol 2017;17:59.

8. Shinde S, Al Balushi Y, Hossny M, Jose S, Al Busaidy S. Factors Affecting the Outcome of Extracorporeal Shockwave Lithotripsy in Urinary Stone Treatment. Oman Med J 2018;33:209-217.

9. Abe T, Akakura K, Kawaguchi M, Ueda T, Ichikawa T, Ito H, Nozumi K, Suzuki K. Outcomes of shockwave lithotripsy for upper urinary-tract stones: a large-scale study at a single institution. J Endourol 2005;19:768-773.

10. Lee HY, Yang YH, Lee YL, Shen JT, Jang MY, Shih PM, Wu WJ, Chou YH, Juan YS. Noncontrast computed tomography factors that predict the renal stone outcome after shock wave lithotripsy. Clin Imaging 2015;39:845-850.

11. Srisubat A, Potisat $S$, Lojanapiwat B, Setthawong V, Laopaiboon M. Extracorporeal shock wave lithotripsy (ESWL) versus percutaneous nephrolithotomy (PCNL) or retrograde intrarenal surgery (RIRS) for kidney stones. Cochrane Database Syst Rev 2009:CD007044.

12. Nafie S, Dyer JE, Minhas JS, Mills JA, Khan MA. Efficacy of a mobile lithotripsy service: a one-year review of 222 patients. Scand J Urol 2014;48:324-327.

13. Sorensen $\mathrm{CM}$, Chandhoke PS. Is lower pole caliceal anatomy predictive of extracorporeal shock wave lithotripsy success for primary lower pole kidney stones? J Urol 2002;168:2377-2382.

14. Obek C, Onal B, Kantay K, Kalkan M, Yalcin V, Oner A, Solok V, Tansu N. The efficacy of extracorporeal shock wave lithotripsy for isolated lower pole calculi compared with isolated middle and upper caliceal calculi. J Urol 2001;166:2081-2084.

15. Torricelli FC, Danilovic A, Vicentini FC, Marchini GS, Srougi M, Mazzucchi E. Extracorporeal shock wave lithotripsy in the treatment of renal and ureteral stones. Rev Assoc Med Bras (1992) 2015;61:65-71.

16. Al-Ansari A, As-Sadiq K, Al-Said S, Younis N, Jaleel OA, Shokeir AA. Prognostic factors of success of extracorporeal shock wave lithotripsy (ESWL) in the treatment of renal stones. Int Urol Nephrol 2006;38:63-67.

17. Elbahnasy AM, Clayman RV, Shalhav AL, Hoenig DM, Chandhoke P, Lingeman JE, Denstedt JD, Kahn R, Assimos DG, Nakada SY. Lower-pole caliceal stone clearance after shockwave lithotripsy, percutaneous nephrolithotomy, and flexible ureteroscopy: impact of radiographic spatial anatomy. J Endourol 1998;12:113-119.

18. Perks AE, Schuler TD, Lee J, Ghiculete D, Chung DG, D'A Honey RJ, Pace KT. Stone attenuation and skin-to-stone distance on computed tomography predicts for stone fragmentation by shock wave lithotripsy. Urology 2008;72:765-769.

19. Bon $D$, Dore $B$, Irani J, Marroncle $M$, Aubert J. Radiographic prognostic criteria for extracorporeal shock-wave lithotripsy: a study of 485 patients. Urology 1996;48:556-561.

20. Mandhani A, Raghavendran $M$, Srivastava $A$, Kapoor $R$, Singh $U$, Kumar A, Bhandari M. Prediction of fragility of urinary calculi by dual X-ray absorptiometry. J Urol 2003;170:1097-1100.

21. Junbo L, Yugen L, Guo J, Jing $H$, Ruichao $Y$, Tao W. Retrograde Intrarenal Surgery vs. Percutaneous Nephrolithotomy vs. Extracorporeal Shock Wave Lithotripsy for Lower Pole Renal Stones 10-20 mm: A Meta-analysis and Systematic Review. Urol J 2019;16:97-106. 